\title{
Stability Analysis and Confidence Level Evaluation of Backfill Mining under High and Steep Rock Slopes
}

\author{
Bo-yi Hu, ${ }^{1}$ Xin-min Wang, ${ }^{1}$ Shuai Li $\left(\mathbb{D},{ }^{1}\right.$ Jian-wen Zhao, ${ }^{2}$ and Nyandwe Musonda Eugénie ${ }^{1}$ \\ ${ }^{1}$ School of Resources and Safety Engineering, Central South University, Changsha 410083, China \\ ${ }^{2}$ Changsha Green Mine Environmental Technology Co., Ltd., Changsha 410004, China \\ Correspondence should be addressed to Shuai Li; 15200826420@163.com
}

Received 29 May 2018; Revised 31 August 2018; Accepted 16 September 2018; Published 21 October 2018

Academic Editor: Roman Wan-Wendner

Copyright $\odot 2018$ Bo-yi Hu et al. This is an open access article distributed under the Creative Commons Attribution License, which permits unrestricted use, distribution, and reproduction in any medium, provided the original work is properly cited.

\begin{abstract}
To extract the 6.3 million tons of high-quality phosphate resources, a stability analysis and confidence level evaluation of backfill mining under high and steep rock slopes (HSRS) were conducted using the Slide software and a Monte Carlo simulation. The geological model of HSRS was constructed based on a geotechnical investigation. A series of laboratory tests were conducted to obtain the engineering parameters of the rock mass, and the mechanism of action of the backfill mining method was analyzed. After the stability analysis, the average safety factors of HSRS for normal operation are 1.575 (backfill method) and 1.509 (openstope method), and for seismic conditions, they are 1.470 (backfill method) and 1.380 (open-stope method). According to the confidence level evaluation, the average failure probability of HSRS by using the backfill mining method is 0.0143 . The results showed that using the backfill mining method under HSRS had better seismic stability and lower potential levels of destruction than using the traditional open-stope mining method. In addition, the backfill mining method can prevent the development of a circular failure surface, reduce the destructive effect of mining to a minimum, and maintain the lower failure probability of HSRS.
\end{abstract}

\section{Introduction}

Cemented tailings backfill technology, characterized by a mixture of binding material, tailings, and water, has been widely accepted as an environmentally friendly, economical, and effective tailings disposal option for the safe management of underground mining goafs and the removal of significant tailings pollution on the surface $[1,2]$. The superiority of the backfill mining method over the traditional open-stope method is shown in Figure 1, and it comprises, for example, removal of goaf hazards and prevention of surface subsidence, reduction in tailings emissions and environmental protection, pillar replacement with backfills and effective resource recovery, reduction of deep ground temperature and weakening of rock burst, etc.

The increasing demand for mineral resources has led to the gradual depletion of easily mined or abundant ore bodies. Ore bodies with poor mining conditions are then gradually being utilized and exploited. Some of these are under high and steep rock slopes (HSRS), where mining activities may decrease the slope stability, causing landslides and threatening the safety of people and properties nearby. Due to the advantage of removing the underground goaf hazards and preventing surface subsidence, the backfill mining method is widely used in complicated mining conditions, for example, mining under bodies of water, railways or highways, and buildings [3-5] (Table 1).

Most previous studies on mining slopes have focused on artificial slopes, such as the recovery of hanging-wall ore in open-pit mine slopes, and research in primary mining slopes is lacking. Therefore, it is of great significance to comprehensively analyze the stability and evaluate the confidence level of backfill mining under primary HSRS. At present, the main methods of slope stability analysis include the limit equilibrium theory, the numerical analysis method, the stochastic analysis method, and the fuzzy analysis method $[6,7]$. The numerical analysis method can be further classified into the finite-element method, the spectral element 


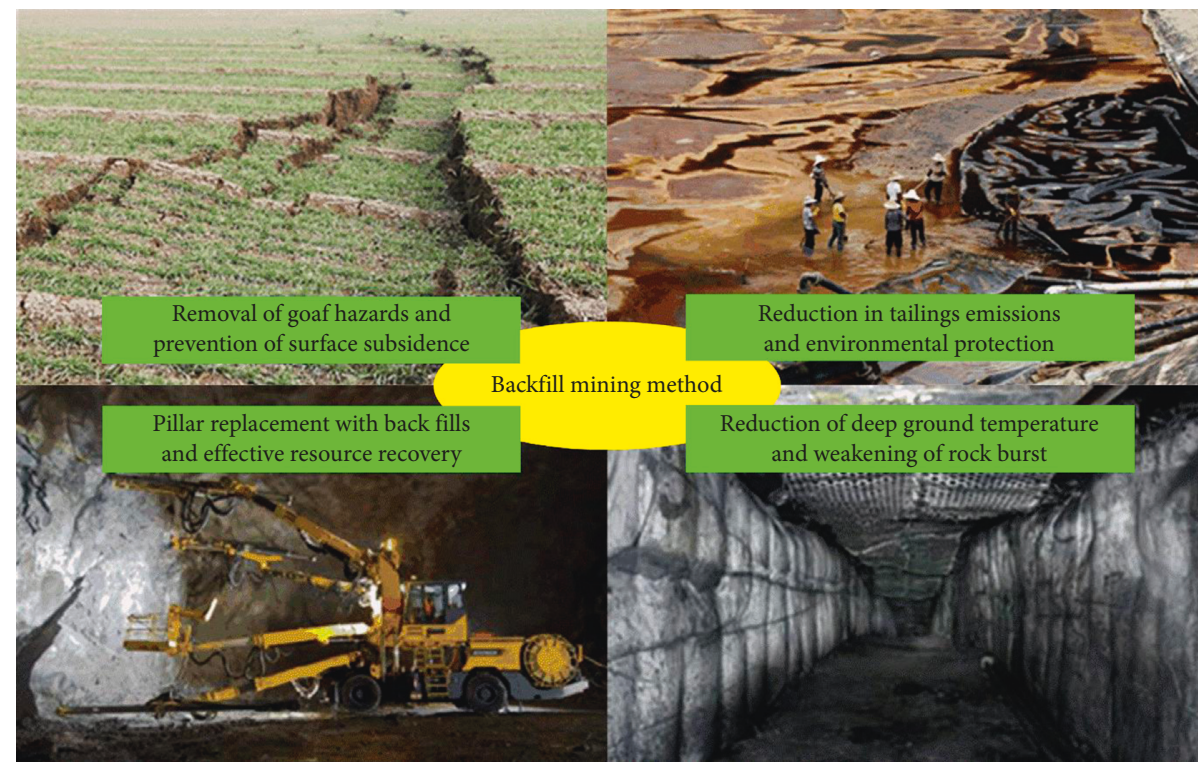

FIGURE 1: Superiority of the backfill mining method over the traditional open-stope method.

TABLE 1: Successful cases of the backfill mining method used in complicated mining conditions.

\begin{tabular}{lcc}
\hline Mine & Location & Background \\
\hline Xinqiao pyrite mine & Tongling, Anhui, China & Mining under railway and high open-pit slopes \\
Dongguashan copper mine & Tongling, Anhui, China & Mining under villages and farmland \\
Baixiangshan iron mine & Ma'anshan, Anhui, China & Mining under Guxi River, a branch of Yangtze \\
Kangjiawan lead-zinc mine & Changnin, Hunan, China & Mining under Xiang River, a branch of Yangtze \\
Kaiyang phosphate mine & Kaiyang, Guiyang, China & Mining under highway and high rock slopes \\
\hline
\end{tabular}

method, the discrete element method, the fast Lagrangian analysis of continua, the discontinuous deformation analysis, and the boundary element method [8]. Due to the complicated and changeable impact factors, such as tectonic movement, the occurrence of slopes, and the mechanical characteristics of the rock mass, groundwater, rainfall, and seismic activity, the stability of HSRS may change and can be difficult to predict with high precision [9]. The basic hypotheses for deterministic analysis methods, such as the limit equilibrium theory and numerical analysis, are usually too idealistic and simplified. This leads to a lack of precision, which is difficult to overcome [10]. Stochastic analysis and fuzzy analysis were developed on the basis of uncertainty, randomness, or fuzziness factors, which can compensate for the deficiency in the deterministic analysis methods $[11,12]$. Macneil and Dimitrakopoulos [13] derived a stochastic optimization formulation for the transition from open-pit to underground mining by jointly considering geological uncertainty and describing the optimal transition depth effectively in three dimensions. Jang et al. [14] established an innovative unplanned dilution and ore-loss management system in underground stoping operations using a neurofuzzy system to overcome the uneven break phenomenon in underground stope blasting. Deng et al. [15] present a mine pillar design approach by combining finite-element methods, neural networks, and reliability analysis.

In this study, the position and geology of a typical primary HSRS in Dingxi Mine (Hubei Province, China) have been described. A series of laboratory tests were conducted to obtain the different engineering parameters of the rock mass. By combining deterministic and stochastic analysis methods, the study attempted to analyze the stability and evaluate the confidence level of HSRS using the Slide software and a Monte Carlo simulation.

\section{Engineering Background}

2.1. Positions of HSRS. Zhangcunping Town is a typical mining town that was built next to the Dingxi Mine and has a total population of 500. High and steep mountains surround the town, forming several HSRS and threatening the safety of the people and properties nearby. To ensure safety, an area containing nearly 6.3 million tons of high-grade phosphate rock resources near the town was defined as a banned area, which shortened the service life and affected the economic benefits of the Dingxi Mine. As there are many HSRS in the banned area, the slope that best reflected slope instability was chosen for analysis. After comparative analysis, a typical primary HSRS located in the southeast, just $200 \mathrm{~m}$ away from a family home, was selected (Figure 2).

2.2. Geology of HSRS. According to the geotechnical investigation, there are 14 layers of gently inclined rock or ore from top to bottom. As the most conservative and safe backfill mining method, the interchanging tunnel mining 


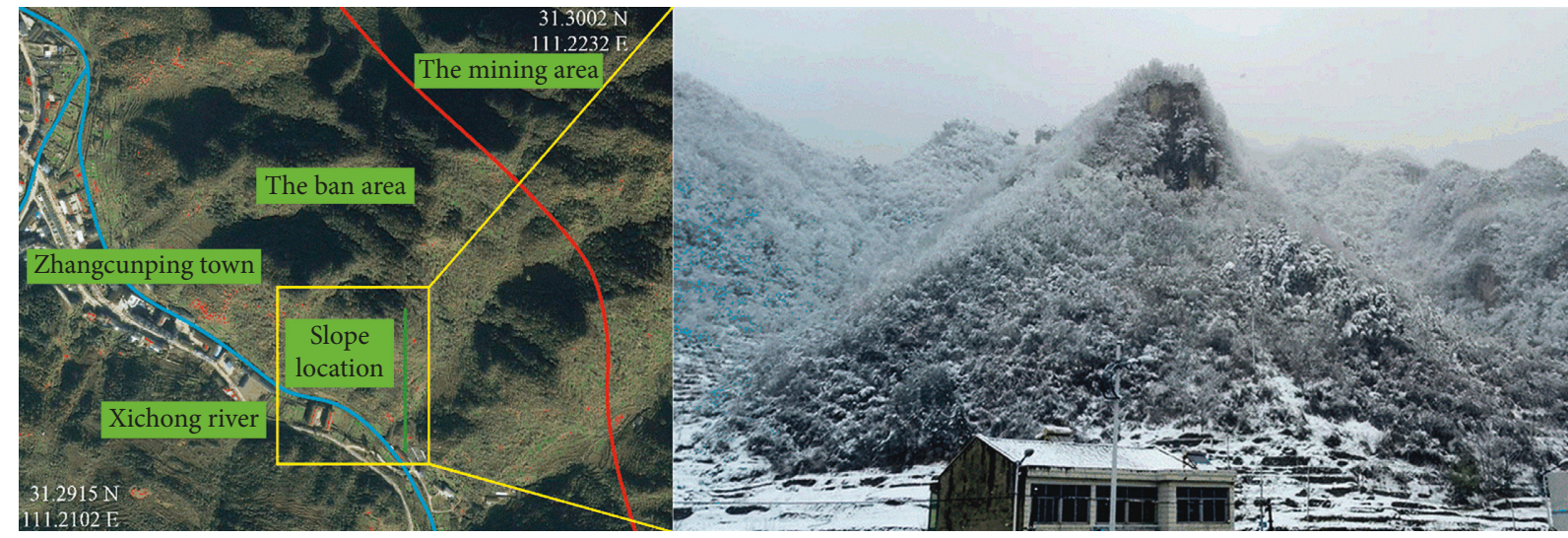

FIgURe 2: Positions and view of the HSRS.

method was suggested on the basis of a careful feasibility study of both technological and economic factors. There is a $50 \mathrm{~m}$ wide safety pillar left on the inner side of the slope, and a strong weathering layer, approximately $5 \mathrm{~m}$ thick, covering the surface of the HSRS. According to the backfill mining plan, the HSRS is in the most dangerous situation when the mined out rooms have been cemented backfilled, and the innermost room is a goaf (Figure 3).

\subsection{Determination of Engineering Parameters of Rock Mass.} An SHT4206 electro-hydraulic servo universal testing machine (SANS, America) was used to determine the engineering parameters of the rock mass (Figure 4). The results of the uniaxial compressive strength test and splitting tensile strength test are summarized in Tables 2 and 3. Referring to the Technical code for building slope engineering (GB 503302013) [16], and combined with engineering experience [17], the volume-weight, cohesion, and internal friction angle of each rock (ore) layer on the section of slope were determined based on in situ and laboratory test results (Table 4). The Mohr-Coulomb model is chosen for material definition, and the physical and mechanical parameters of each layer are used in the calculation model according to Table 4. Considering that the entire slope was on a riverbed, it is unnecessary to consider the influence of groundwater.

\section{Stability Analysis}

The Slide software was developed by the Rocscience company of Canada and uses limit equilibrium theory to analyze the stability of rock and soil slopes [18]. With builtin finite-element groundwater seepage, the Slide software can not only quickly create and analyze complex models, but also analyze slope stability and failure probability under external load, groundwater, or support. By specifying the parameters of the statistical distribution, such as material properties, support characteristics, load, and groundwater level, the Slide software can interpret the uncertainty of the parameters and calculate the probability of slope landslide [19]. The version of the Slide software used in this research is 6.0 .
3.1. Stability Analysis Method. Nowadays, the limit equilibrium-based methods remain the most popular option in rock slope engineering [17]. Slope stability analysis by the Slide software generally contains two steps. The first step is to calculate the safety factor of a slip surface using limit equilibrium theory. The common methods are Fellenius, simplified Bishop, simplified Janbu, Spencer, MorgensternPrice, and Sarma $[6,20]$. As an improvement on the Fellenius method, the simplified Bishop method shows sufficient accuracy by dividing the sliding body into i slices and assuming a circular failure surface (Figure 5) [21]. The safety factor $F$ of a slip surface is defined as the ratio of the total antisliding moment of slice $i$ to the total sliding moment generated by slice $\mathrm{i}$ and the external load. The expression of $F$ can be described as

$$
F=\frac{\sum\left(c b_{\mathrm{i}}+W_{\mathrm{i}} \tan \theta\right) /\left(\cos \theta_{\mathrm{i}}+\left(\sin \theta_{\mathrm{i}} \tan \theta\right) / F\right)}{\sum W_{\mathrm{i}} \sin \theta_{\mathrm{i}}},
$$

where $c$ is the cohesion of the slip surface in $\mathrm{kPa} ; \varphi$ is the internal friction angle in ${ }^{\circ} ; b_{\mathrm{i}}$ is the width of slice i in $m ; W_{\mathrm{i}}$ is the slice weight in $\mathrm{kN}$; and $\theta_{\mathrm{i}}$ is the sliding angle of slice $\mathrm{i}$ in ${ }^{\circ}$.

The second step is to search for the critical slip surface from all the global minimum slip surfaces using the overall slope method of Slide software. After $N$ iterative searches, each iterative search reloads a new group of random variable samples to complete the search and determine the global minimum slip surface.

3.2. Stability of HSRS in Normal Operation. According to the backfill mining method, the HSRS is in the most dangerous situation when the mined out rooms have been cemented backfilled, and the innermost room is a goaf. In the openstope mining method, the HSRS is in the most dangerous situation when the mined out rooms are all goafs. In order to evaluate the superiority of the backfill mining method over the traditional open-stope method in normal operation, the stabilities of the HSRS in two of its most dangerous situations were calculated using the simplified Bishop method, Fellenius method, and simplified Janbu method $[6,20]$ (Figure 6). 


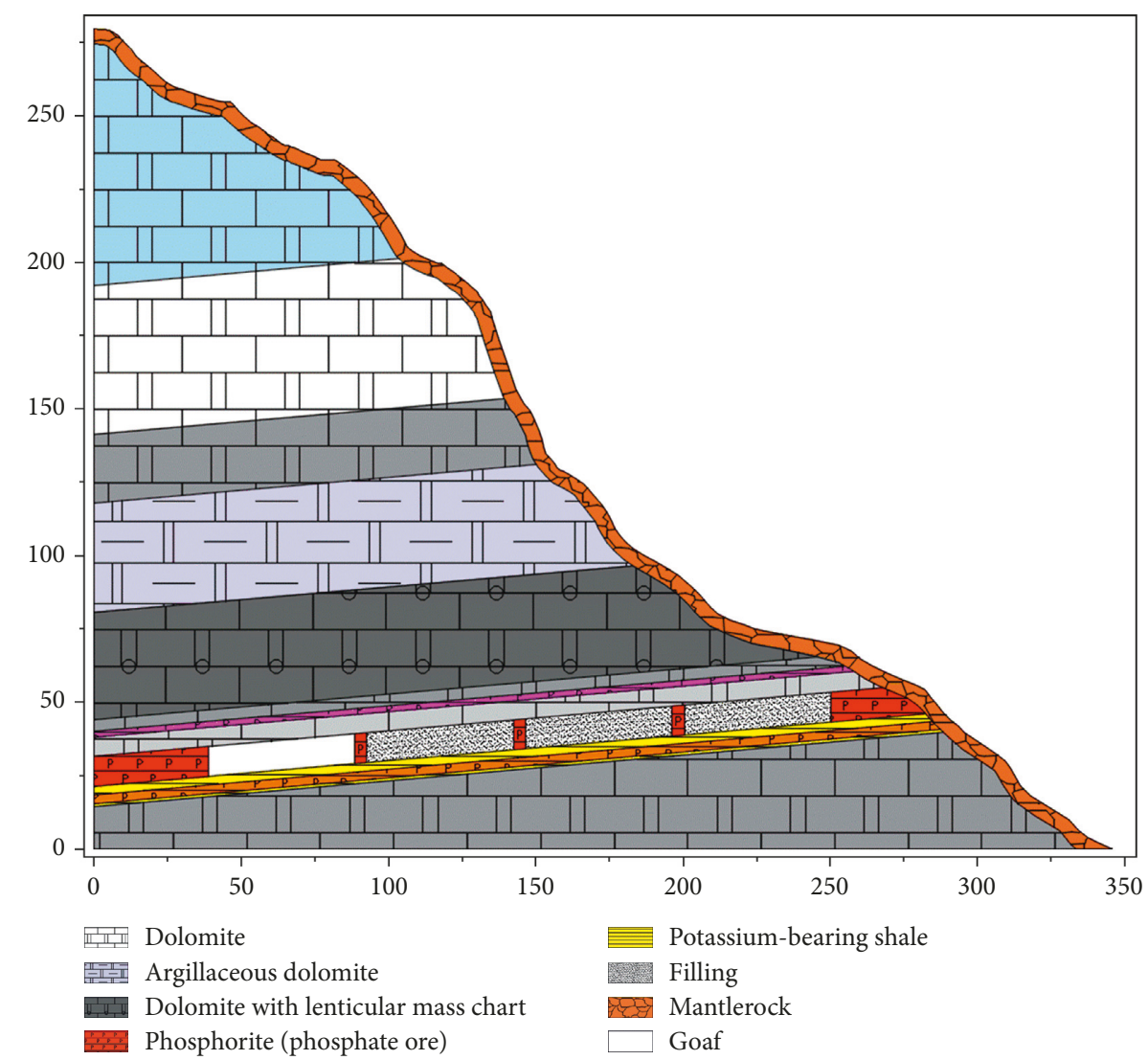

FIgURE 3: The most dangerous situation of HSRS using backfill mining method.

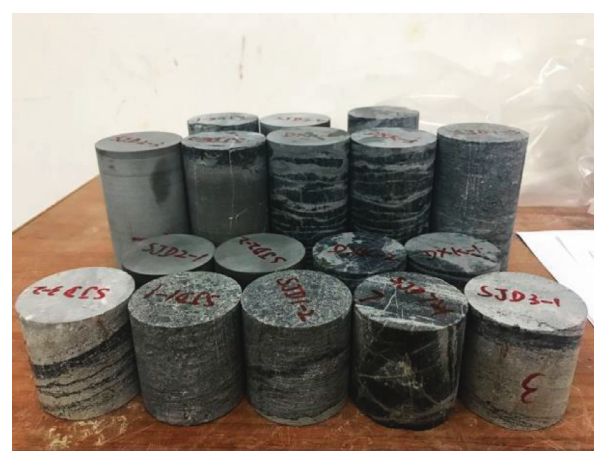

(a)

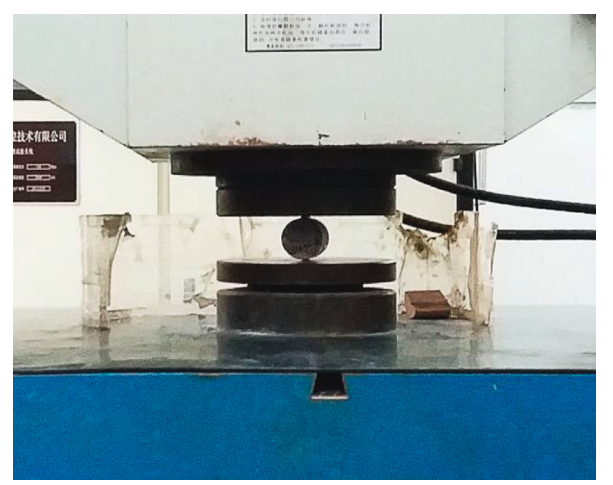

(c)

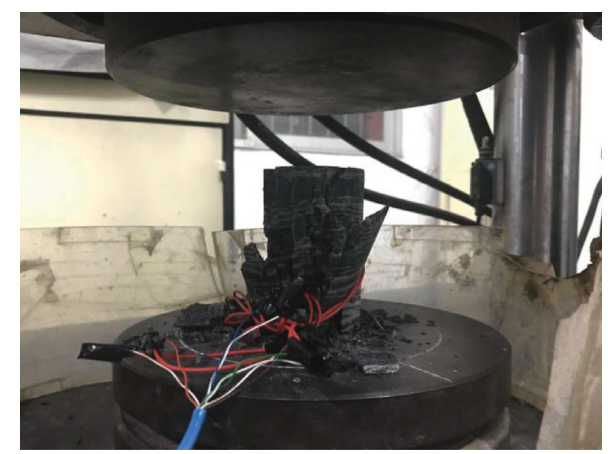

(b)

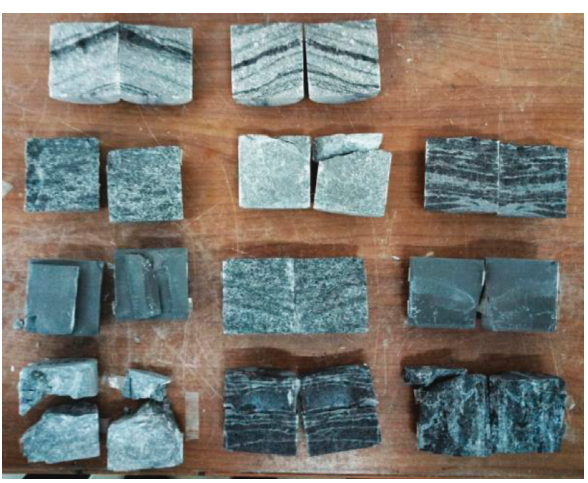

(d)

FIGURE 4: Laboratory test photos: (a) rock specimens; (b) uniaxial compressive strength test; (c) splitting tensile strength test; (d) rock specimens after tests. 
TABLE 2: Uniaxial compressive strength test results.

\begin{tabular}{lcccccc}
\hline Specimen number & Diameter $(\mathrm{mm})$ & $\begin{array}{c}\text { Height } \\
(\mathrm{mm})\end{array}$ & Peak load $(\mathrm{kN})$ & $\begin{array}{c}\text { Elastic modulus } \\
(\mathrm{GPa})\end{array}$ & Poisson's ratio & Uniaxial compressive strength (MPa) \\
\hline DXD-3 & 50.25 & 108.97 & 38.22 & 10.38 & 0.41 & 19.3 \\
DXD-4 & 50.28 & 110.97 & 52.71 & 5.82 & 0.26 & 26.5 \\
DXD-5 & 50.14 & 103.25 & 45.83 & 8.32 & 0.24 & 23.3 \\
DXK-3 & 50.21 & 101.90 & 114.26 & 36.12 & 0.25 & 57.7 \\
DXK-4 & 50.22 & 103.15 & 128.23 & 27.94 & 0.30 & 64.7 \\
DXK-5 & 50.19 & 101.48 & 118.58 & 30.64 & 0.22 & 62.5 \\
\hline
\end{tabular}

TABLE 3: Splitting tensile strength test results.

\begin{tabular}{lcccc}
\hline Specimen number & Diameter $(\mathrm{mm})$ & Height $(\mathrm{mm})$ & Peak load $(\mathrm{kN})$ & Tensile strength $(\mathrm{MPa})$ \\
\hline DXD-1 & 50.16 & 51.12 & 13.52 & 3.36 \\
DXD-2 & 50.19 & 51.44 & 31.16 & 7.68 \\
DXK-1 & 50.23 & 50.77 & 12.18 & 3.04 \\
DXK-2 & 50.23 & 52.19 & 14.77 & 3.59 \\
\hline
\end{tabular}

TABle 4: Physical and mechanical parameters of rock (ore) layers.

\begin{tabular}{|c|c|c|c|c|c|}
\hline \multirow[t]{2}{*}{ Code of stratum } & \multirow[t]{2}{*}{ Name of stratum } & \multicolumn{2}{|c|}{$\begin{array}{c}\text { Volume- } \\
\text { weight }\end{array}$} & \multirow[t]{2}{*}{ Cohesion $\left(\mathrm{kN} / \mathrm{m}^{2}\right)$} & \multirow[t]{2}{*}{ Internal friction angle $\left({ }^{\circ}\right)$} \\
\hline & & $\mathrm{t} / \mathrm{m}^{3}$ & $\mathrm{kN} / \mathrm{m}^{3}$ & & \\
\hline $\mathrm{Z}_{2} \mathrm{dn}_{2}$ & Grey dolomite & 2.76 & 27.08 & 470 & 36 \\
\hline $\mathrm{Z}_{2} \mathrm{dn}_{1}$ & Light grey dolomite & 2.76 & 27.08 & 470 & 36 \\
\hline $\mathrm{Z}_{2} \mathrm{~d}_{4}$ & Grey-charcoal grey dolomite & 2.74 & 26.88 & 450 & 36 \\
\hline $\mathrm{Z}_{2} \mathrm{~d}_{3}$ & Grey_charcoal grey argillaceous dolomite & 2.70 & 26.49 & 430 & 36 \\
\hline $\mathrm{Z}_{2} \mathrm{~d}_{2}^{2}$ & Black dolomite with lenticular mass chert & 2.80 & 27.47 & 480 & 36 \\
\hline $\mathrm{Z}_{2} \mathrm{~d}_{2}{ }^{1}$ & Grey dolomite & 2.75 & 26.98 & 460 & 36 \\
\hline $\mathrm{Ph}_{2}$ & Grey dolomitic phosphorite & 2.95 & 28.94 & 500 & 39 \\
\hline $\mathrm{Z}_{2} \mathrm{~d}_{1}{ }^{3}$ & Grey thick-layer dolomite & 2.78 & 27.27 & 480 & 36 \\
\hline $\mathrm{Ph}_{1}{ }^{3}$ & $\begin{array}{l}\text { Grey dolomitic phosphorite, grey black tight } \\
\text { phosphorite, black argillaceous phosphorite }\end{array}$ & 2.93 & 28.74 & 490 & 39 \\
\hline $\mathrm{K}_{2}$ & Potassium-bearing shale & 2.68 & 26.29 & 330 & 25 \\
\hline $\mathrm{Ph}_{1}^{2}$ & Black argillaceous sandy phosphorite & 2.90 & 28.45 & 480 & 39 \\
\hline $\mathrm{K}_{1}$ & Potassium-bearing shale & 2.68 & 26.29 & 330 & 25 \\
\hline $\mathrm{Z}_{2} \mathrm{~d}_{1}^{2}$ & Grey dolomite & 2.72 & 26.68 & 440 & 36 \\
\hline Mantlerock & The strong weathering layer & 2.50 & 24.53 & 150 & 20 \\
\hline Backfill & Cemented backfill & 1.95 & 19.13 & 200 & 22 \\
\hline
\end{tabular}

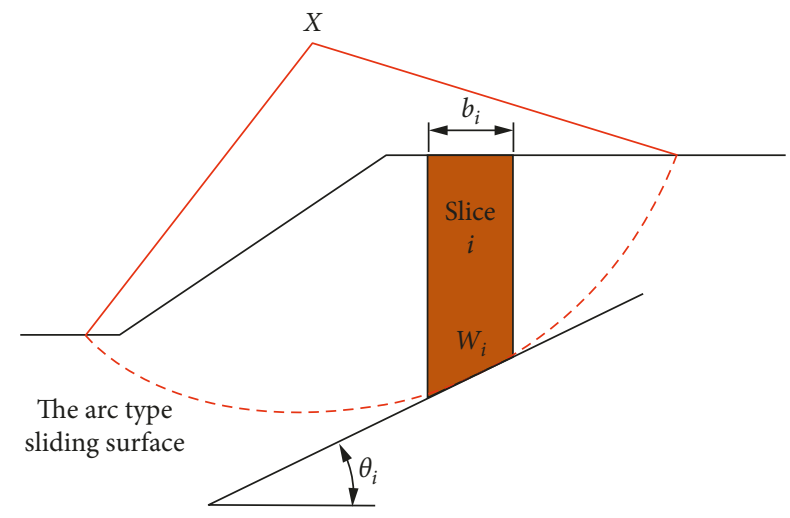

FIgURE 5: Schematic diagram of the simplified Bishop method.

Due to the lack of special standards for the stability safety factor of slopes disturbed by underground mining, we referred to the Chinese Technical code for building slope engineering (GB 50330-2013), the Code for investigation of geotechnical engineering (GB 50021-2001) [22], and the Technical code for non-coal open-pit mine slope engineering (GB 51016-2014) [23], and selected the biggest value, 1.50, as the standard slope safety factor.

As shown in Figure 6, the safety factors of HSRS in the open-stope method using the simplified Bishop, Fellenius, and simplified Janbu methods for normal operation are $1.561,1.480$, and 1.485 , respectively. Two of them are less than the biggest standard value of 1.50 . This shows that the HSRS is in the limit equilibrium state and has a high chance of landslide using the open-stope method. The safety factors of HSRS in the backfill method using the simplified Bishop, Fellenius, and simplified Janbu method are 1.636, 1.551, and 1.539, respectively. All of these safety factors exceed the biggest standard value of 1.50. Timely backfilling of the goafs reduced the destructive effect caused by mining to a minimum. 


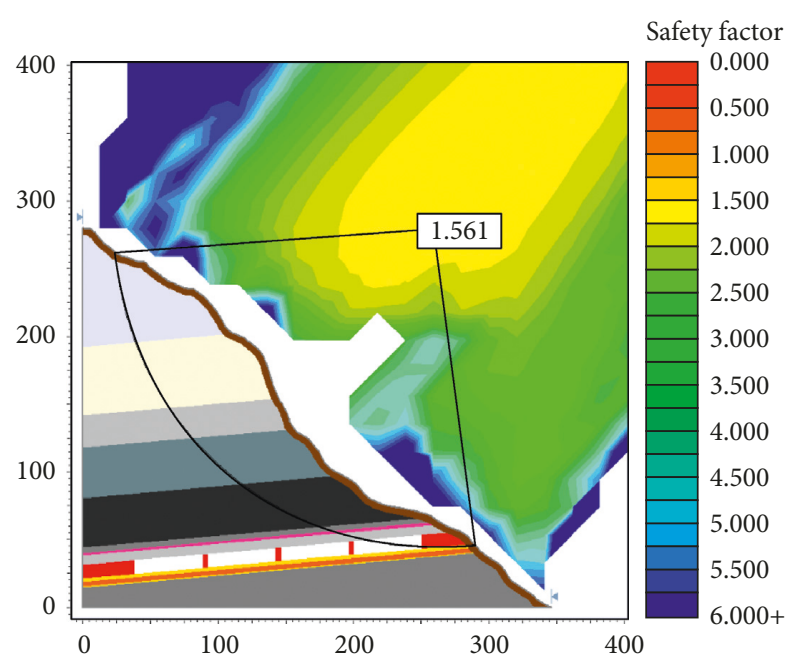

(a)

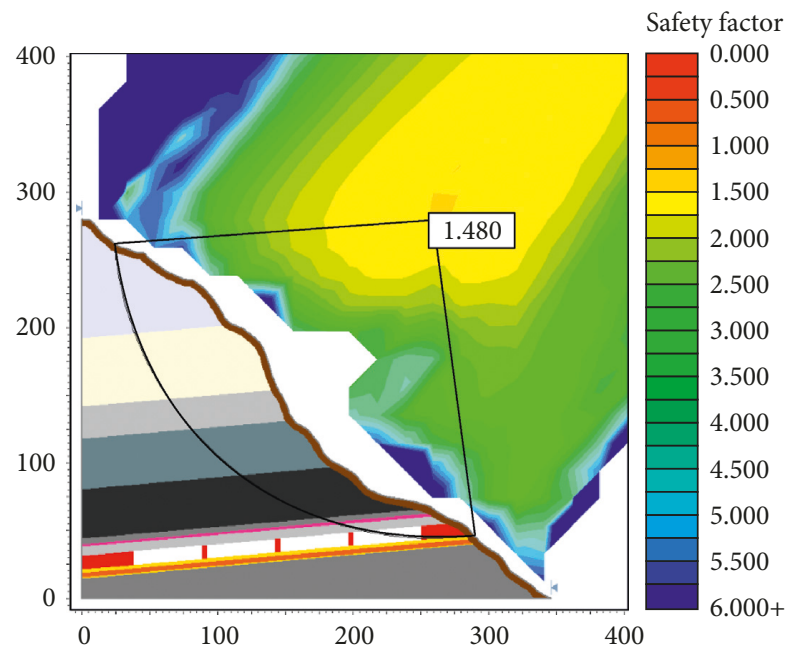

(c)

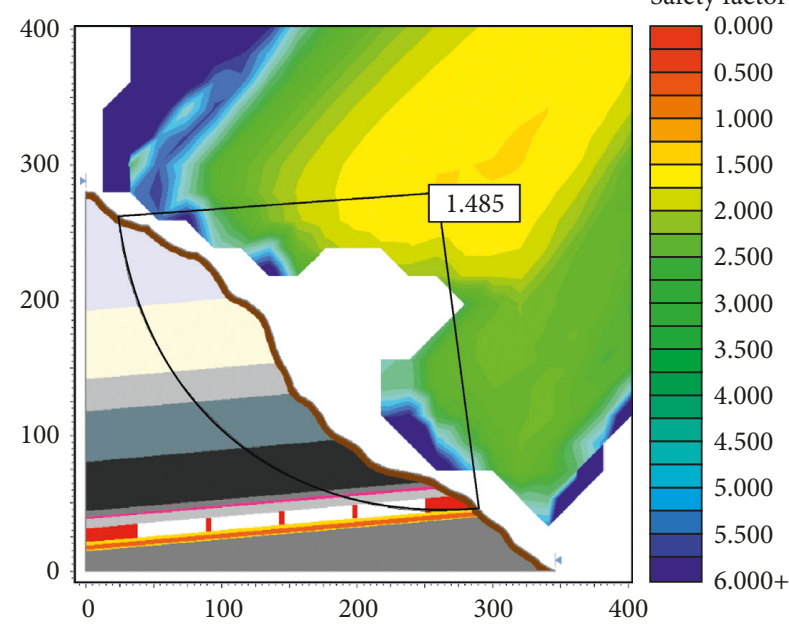

(e)

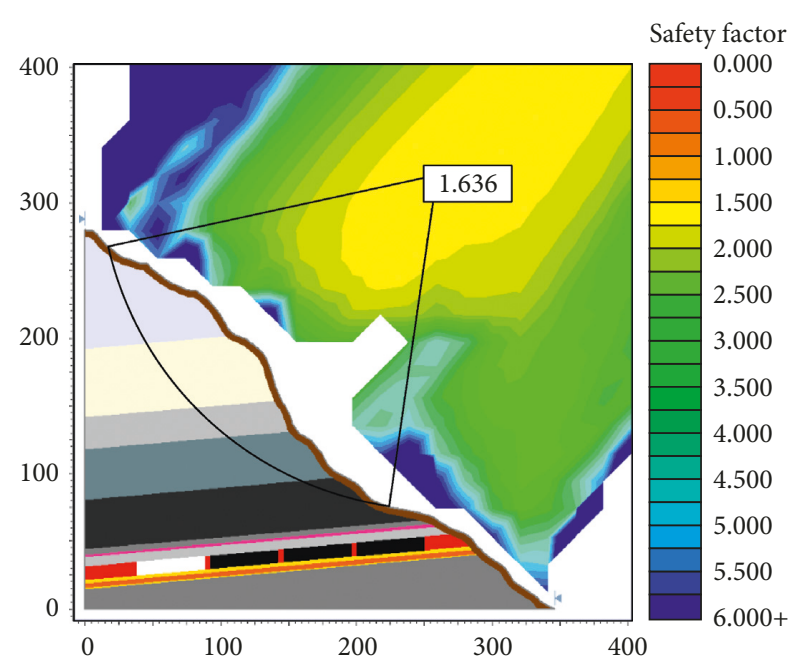

(b)

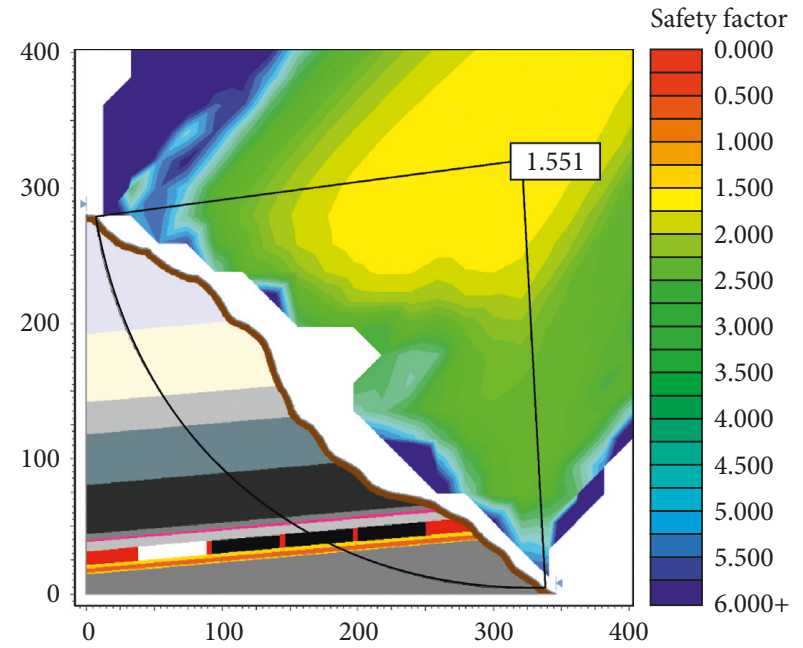

(d)

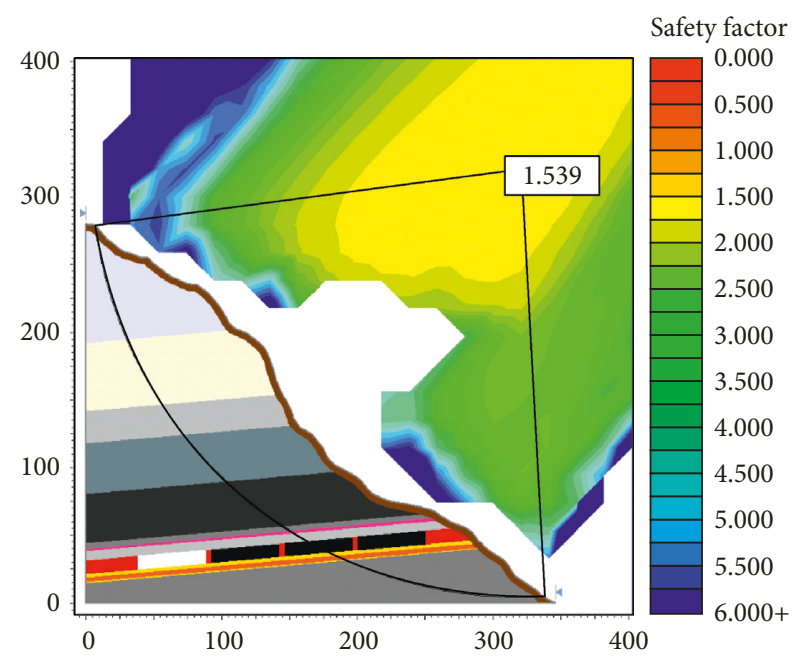

(f)

FIGURE 6: Safety factors of HSRS in normal operation: (a) open-stope method using simplified Bishop method; (b) backfill method using simplified Bishop method; (c) open-stope method using Fellenius method; (d) backfill method using Fellenius method; (e) open-stope method using simplified Janbu method; (f) backfill method using simplified Janbu method. 
3.3. Seismic Stability of HSRS. Earthquakes can have a considerable destructive effect. According to the Seismic ground motion parameters zonation map of China (GB 18306-2015) [24] and the Code for seismic design of buildings (GB 500112010) [25], the seismic fortification intensity of the Dingxi Mine is 6 degrees. The ground motion peak acceleration is then set to $0.05 \mathrm{~g}$, the horizontal seismic load coefficient to 0.04 , and the vertical seismic load coefficient to 0.026 . The special standard which is for the stability safety factor of slopes disturbed by underground mining under seismic conditions has also not been specified. According to three Chinese standards, the standard slope safety factor of HSRS for seismic conditions was set to the biggest value, 1.40. The calculations are shown in Figure 7.

In seismic conditions, the safety factors of HSRS in the backfill method using the simplified Bishop, Fellenius, and simplified Janbu method are 1.536, 1.445, and 1.428, respectively. All of them exceed the biggest standard value of 1.40. With an average safety factor of 1.380, the HSRS in the open-stope method shows substantially lower seismic stability and high levels of potential destruction. The calculated safety factors of the HSRS in the abovementioned situations are shown in Table 5. As the most conservative method of the three, the simplified Janbu method is the most reliable for the Slide analysis and the supporting design.

\section{Confidence Level Evaluation}

Due to the heterogeneity of the slope rock mass and the existence of various internal weak structural planes, it is impossible to take all the factors into account quantitatively [26]. The calculated safety factor of HSRS that meets the design requirements may not necessarily reflect the practical situation, and a supplementary confidence level evaluation of HSRS is required.

4.1. Confidence Level Evaluation Method. With the extensive application of the confidence level analysis method in slope engineering, Monte Carlo simulation has been proven to be a simple and robust method to evaluate the system confidence level of slope stability, particularly in spatially variable rocks [27]. The process of Monte Carlo simulation for the confidence level evaluation of backfill mining under HSRS is summarized as follows. When the probability distribution of the basic variable $X$ is known, an appropriate random number generator can be used to generate a set of random numbers, $x_{1}, \ldots, x_{n}$, that matches the probability distribution of the state variable $X$. These random numbers are then substituted into the state function $g\left(X_{1}, \ldots, X_{n}\right)$ to calculate another set of random numbers $g\left(x_{1}, \ldots, x_{n}\right)$ to determine whether they are less than zero [28]. The $M$ random data of the state function are generated in the same way. If the $M$ random numbers of the state function have $m$ less than zero, then when $M$ is large enough, the law of large numbers shows that the failure probability of the system is

$$
P_{\mathrm{f}}=P\left(g\left(x_{1}, \ldots, x_{n}\right)<0\right)=\frac{m}{M},
$$

where $P_{\mathrm{f}}$ is the failure probability, $m$ is the number of state functions, and $M$ is the number of random data.

4.2. Confidence Level Evaluation of HSRS. To further verify the superiority of the backfill mining method over the traditional open-stope mining method, the confidence level of HSRS was evaluated by the Slide software using a Monte Carlo simulation. By inputting the cohesion and internal friction angles of different materials based on a normal distribution, the confidence level analysis of HSRS in normal operation was conducted based on the critical deterministic slip surface (CDSS), the overall slope method (OSM), the critical probabilistic surface in normal distribution (CPSN), and the critical probabilistic surface in lognormal distribution (CPSL) [18].

The confidence level analysis results based on different analysis methods are shown in Figure 8. The relative frequency distribution for the safety factor of the CPSN is shown in Figure 9, and the results are summarized in Table 6. By using CDSS, OSM, CPSN, and SPSL, the calculated failure probability is $0.0201,0.0165,0.0070$, and 0.0136 , respectively, and the average is 0.0143 ; the reliability index in normal distribution is $13.311,14.677,10.722$, and null, respectively, and the average is 12.903 ; the reliability index in lognormal distribution is $16.850,18.513$, null, and 14.316, respectively, and the average is 16.560 ; and the mean safety factor is $1.637,1.624,2.676$, and 1.722 , respectively, and the average is 1.915. Taking the critical probabilistic surface (in normal distribution) as an example (Figure 9), the relative frequency distribution is approximately a normal distribution. There are 105 values that are less than the Chinese standard value of 1.50 , and the probability of failure is 0.0070 . The number of random data $M=15000$ satisfies $(M \geq$ $100 / P_{\mathrm{f}}$ ), and this can guarantee accuracy [29]. As can be seen from the results, the HSRS has a low failure probability and high reliability index. Therefore, the backfill method can reduce the destructive effect of mining to a minimum and ensure the stability of the HSRS.

\section{Mechanism Analysis}

Research into the formation mechanisms, evolution processes, and destructiveness of slope failure plays an important role in disaster prevention and loss reduction. Unstable rock is the weakest one to study in disasters, and damage and fracture of control fissure under loads is one key technique in the study of the development mechanisms in unstable rock [30]. Due to the existence of a large number of small joint fissures in the structural plane [31], the characteristics of unstable rocks are similar to the soil particles of a soil slope. Under the influence of different disasterinducing factors like rainfall, weathering, earthquakes, and mining, the HSRS is in a complex stress field, and the failure surface is circular [32]. From the aforementioned analysis, we can know that using the backfill mining method for HSRS shows substantially better stability and reliability compared with using the open-stope mining method. The mechanism of action of the backfill mining method in 
Safety factor

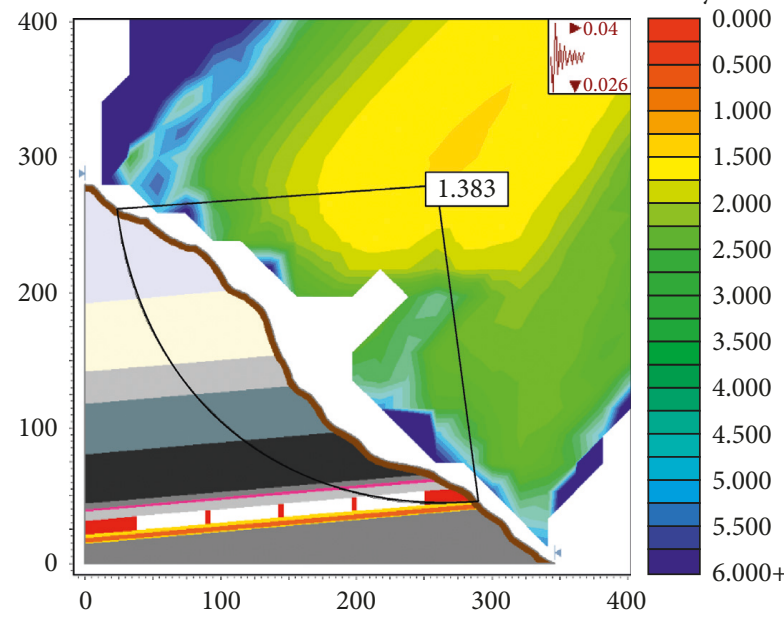

(a)

Safety factor

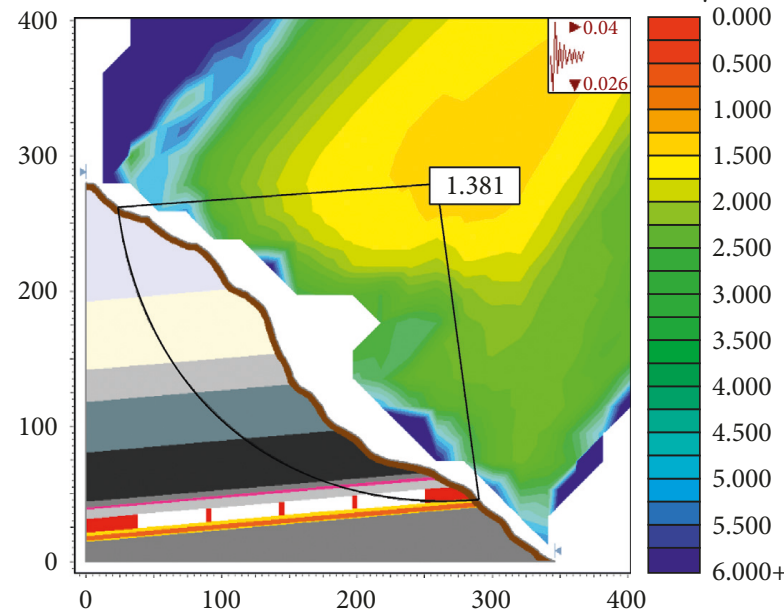

(c)

Safety factor

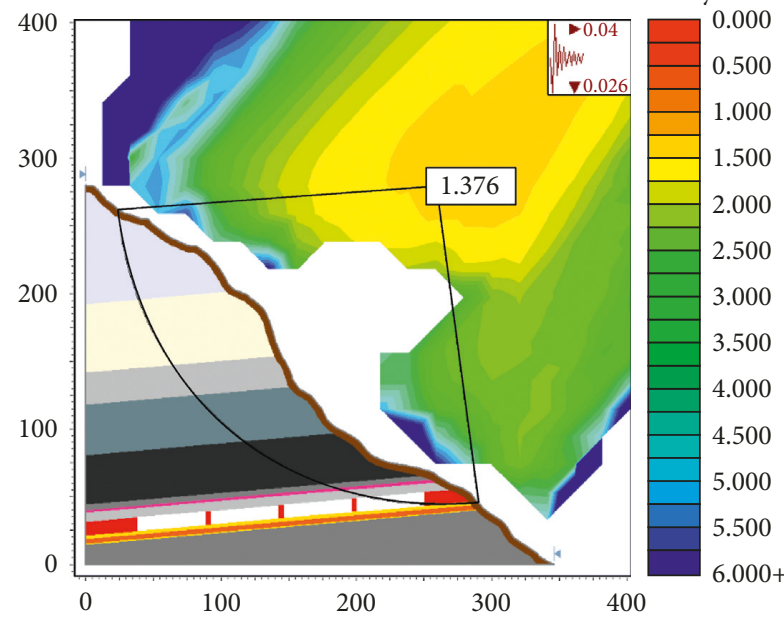

(e)

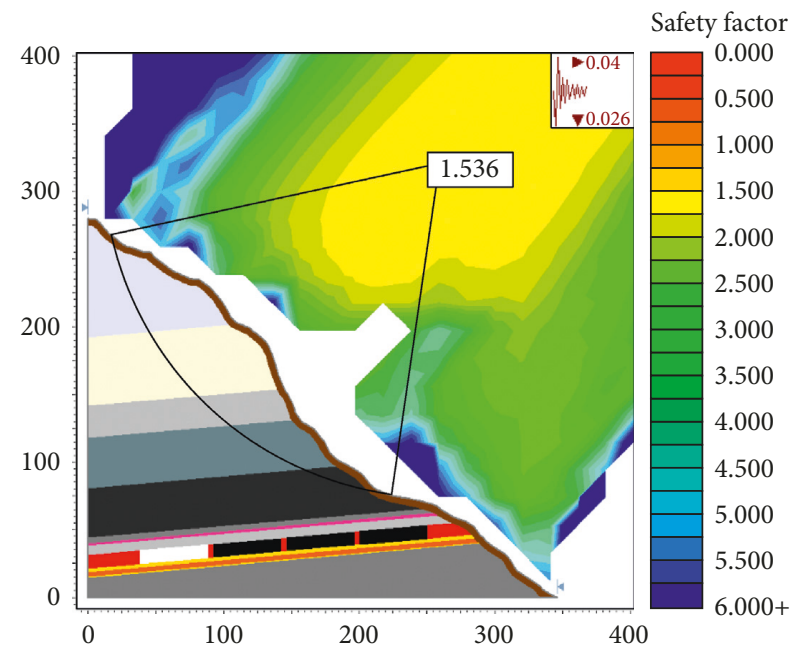

(b)

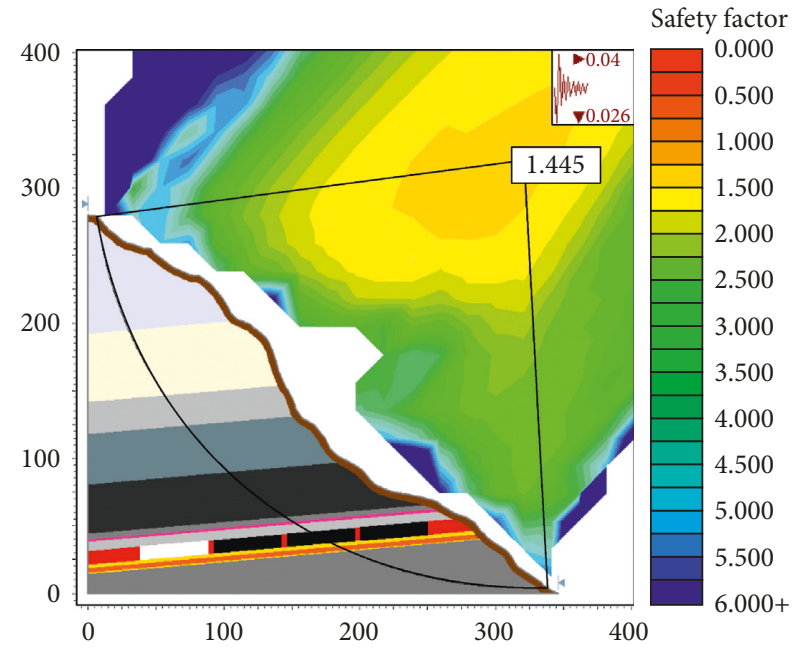

(d)

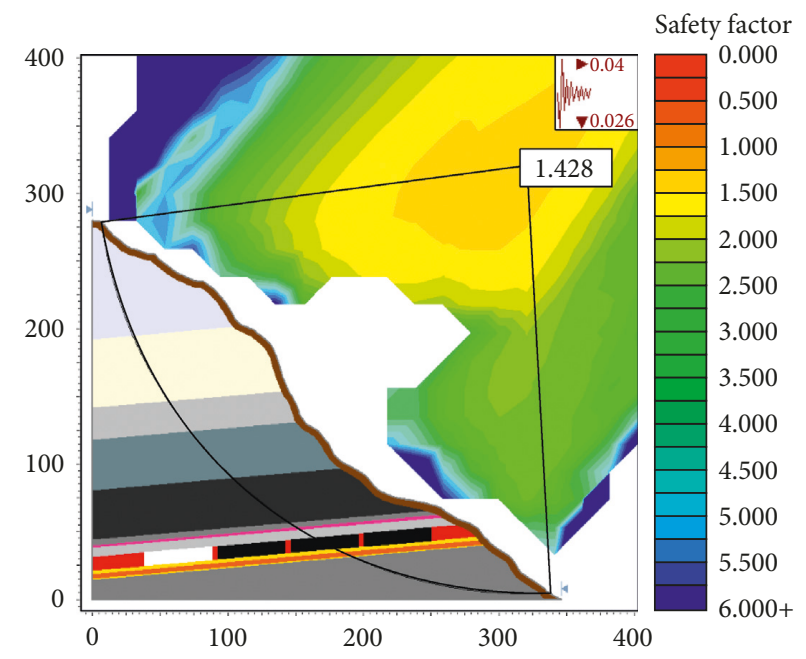

(f)

FIGURE 7: Safety factors of HSRS for seismic conditions: (a) open-stope method using simplified Bishop method; (b) backfill method using simplified Bishop method; (c) open-stope method using Fellenius method; (d) backfill method using Fellenius method; (e) open-stope method using simplified Janbu method; (f) backfill method using simplified Janbu method. 
TABLE 5: Standard values and the calculated stability safety factors of HSRS.

\begin{tabular}{|c|c|c|c|c|c|}
\hline \multirow{2}{*}{ Items } & \multirow{2}{*}{ Codes or methods } & \multicolumn{2}{|c|}{ In normal operation } & \multicolumn{2}{|c|}{ In seismic conditions } \\
\hline & & Open-stope & Backfill & Open-stope & Backfill \\
\hline \multirow{3}{*}{ Calculation results } & Simplified Bishop method & 1.561 & 1.636 & 1.383 & 1.536 \\
\hline & Fellenius method & 1.480 & 1.551 & 1.381 & 1.445 \\
\hline & Simplified Janbu method & 1.485 & 1.539 & 1.376 & 1.428 \\
\hline Average calculation & & 1.509 & 1.575 & 1.380 & 1.470 \\
\hline \multirow{3}{*}{ Chinese standard values } & Code for investigation of geotechnical engineering & \multicolumn{2}{|c|}{$1.30 \sim 1.50$} & \multicolumn{2}{|c|}{$1.20 \sim 1.40$} \\
\hline & Technical code for building slope engineering & \multicolumn{2}{|c|}{1.35} & \multicolumn{2}{|c|}{1.15} \\
\hline & $\begin{array}{c}\text { Technical code for noncoal open-pit mine slope } \\
\text { engineering }\end{array}$ & \multicolumn{2}{|c|}{$1.20 \sim 1.25$} & \multicolumn{2}{|c|}{$1.15 \sim 1.20$} \\
\hline Biggest standard values & & \multicolumn{2}{|c|}{1.50} & \multicolumn{2}{|c|}{1.40} \\
\hline
\end{tabular}

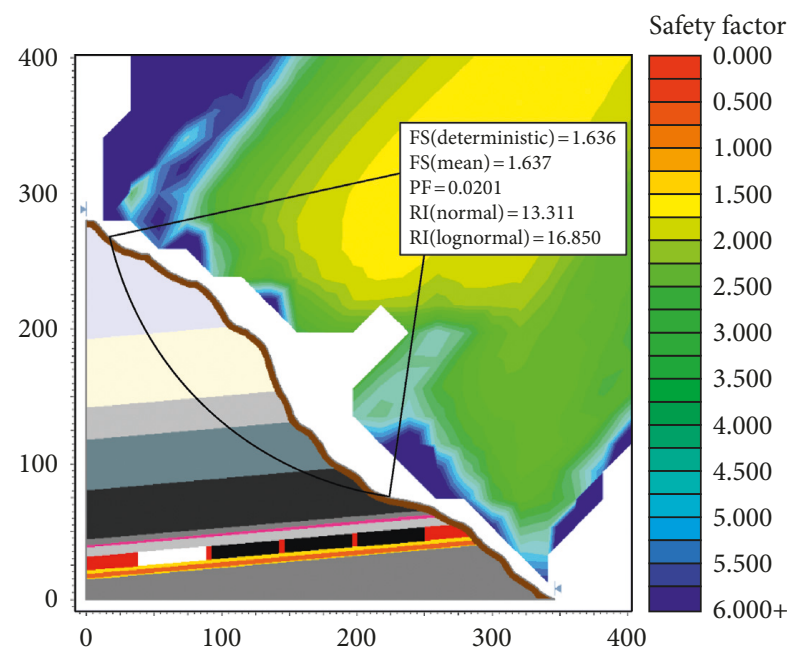

(a)

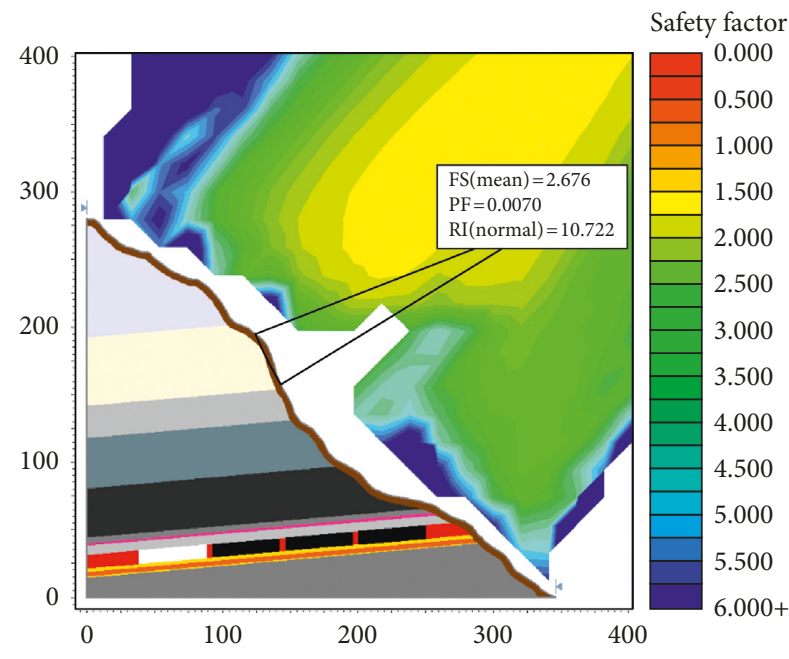

(c)

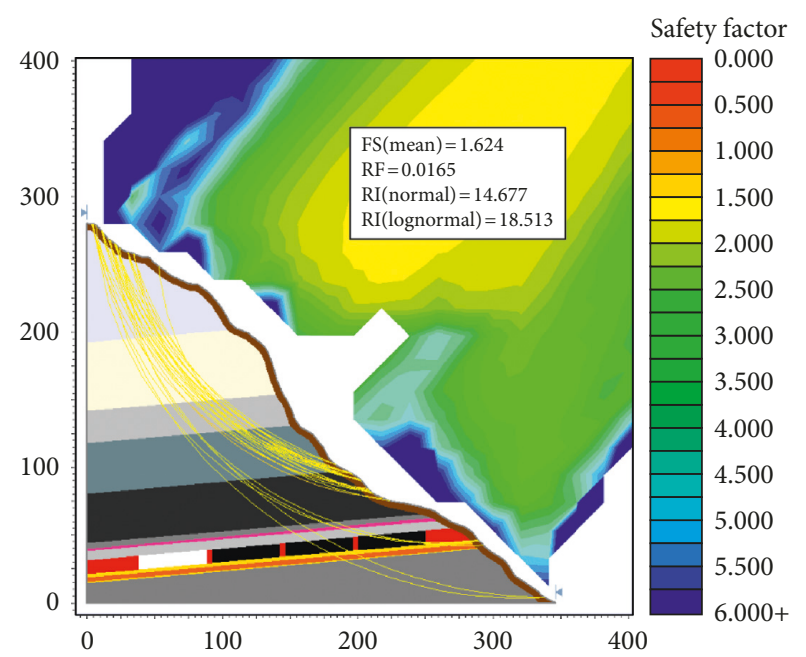

(b)

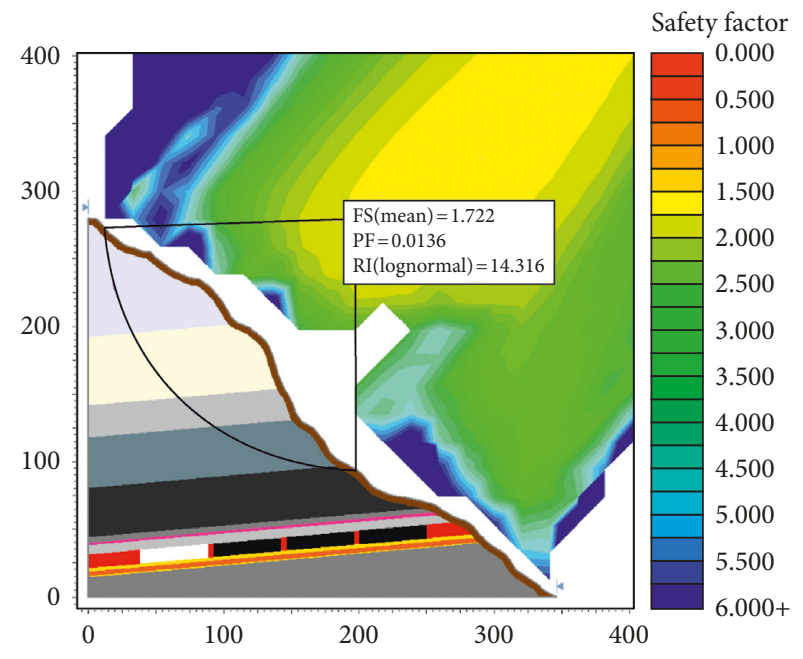

(d)

Figure 8: Confidence level analysis results: (a) CDSS; (b) OSM; (c) CPSN; (d) CPSL.

improving the stability and reliability of HSRS can be divided into four stages, as shown in Figure 10.

As we can see from Figure 10(a), many microcracks appear around the natural defects and structural planes of the primary rock slope, which can be seen as key units that play important roles in the slide evolution [33]. In the case of the open-stope mining method, long-exposed goafs that cut through microcracks cause stress concentration and accelerate crack extension (Figure 10(b)). With the accumulation of microcracks propagating, nucleating, and coalescing, excessive crack extension leads to a decrease in the strength of key units, accelerates the propagation rate of the failure 


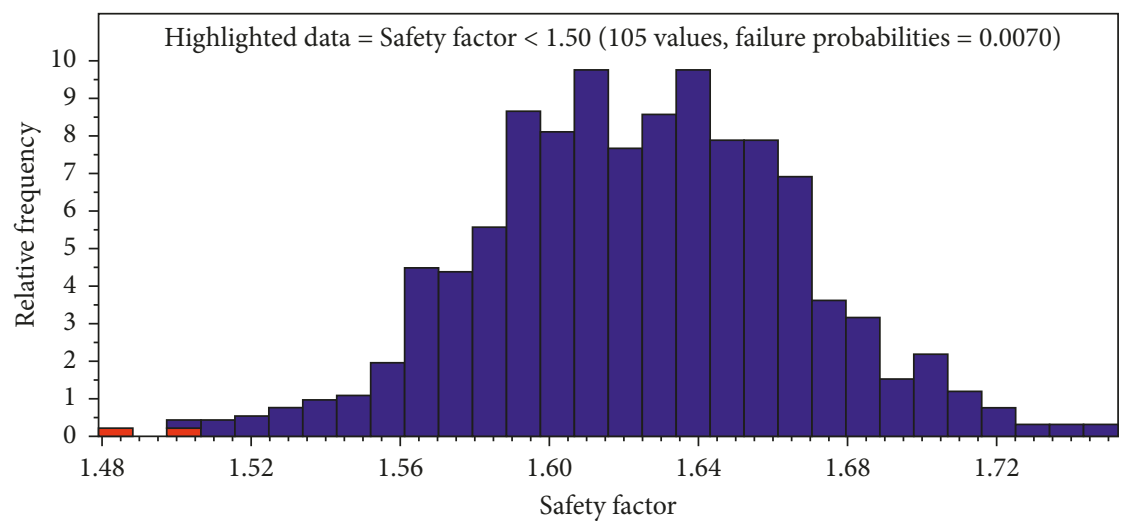

FIgURE 9: The relative frequency distribution for the safety factor of CPSN.

TABLe 6: Confidence level analysis results.

\begin{tabular}{|c|c|c|c|c|}
\hline \multirow{2}{*}{ Analysis methods } & \multirow{2}{*}{ Failure probabilities } & \multicolumn{2}{|c|}{ Reliability index } & \multirow{2}{*}{ Mean safety factor } \\
\hline & & Normal & Lognormal & \\
\hline CDSS & 0.0201 & 13.311 & 16.850 & 1.637 \\
\hline OSM & 0.0165 & 14.677 & 18.513 & 1.624 \\
\hline CPSN & 0.0070 & 10.722 & - & 2.676 \\
\hline OPSL & 0.0136 & - & 14.316 & 1.722 \\
\hline Average value & 0.0143 & 12.903 & 16.560 & 1.915 \\
\hline
\end{tabular}

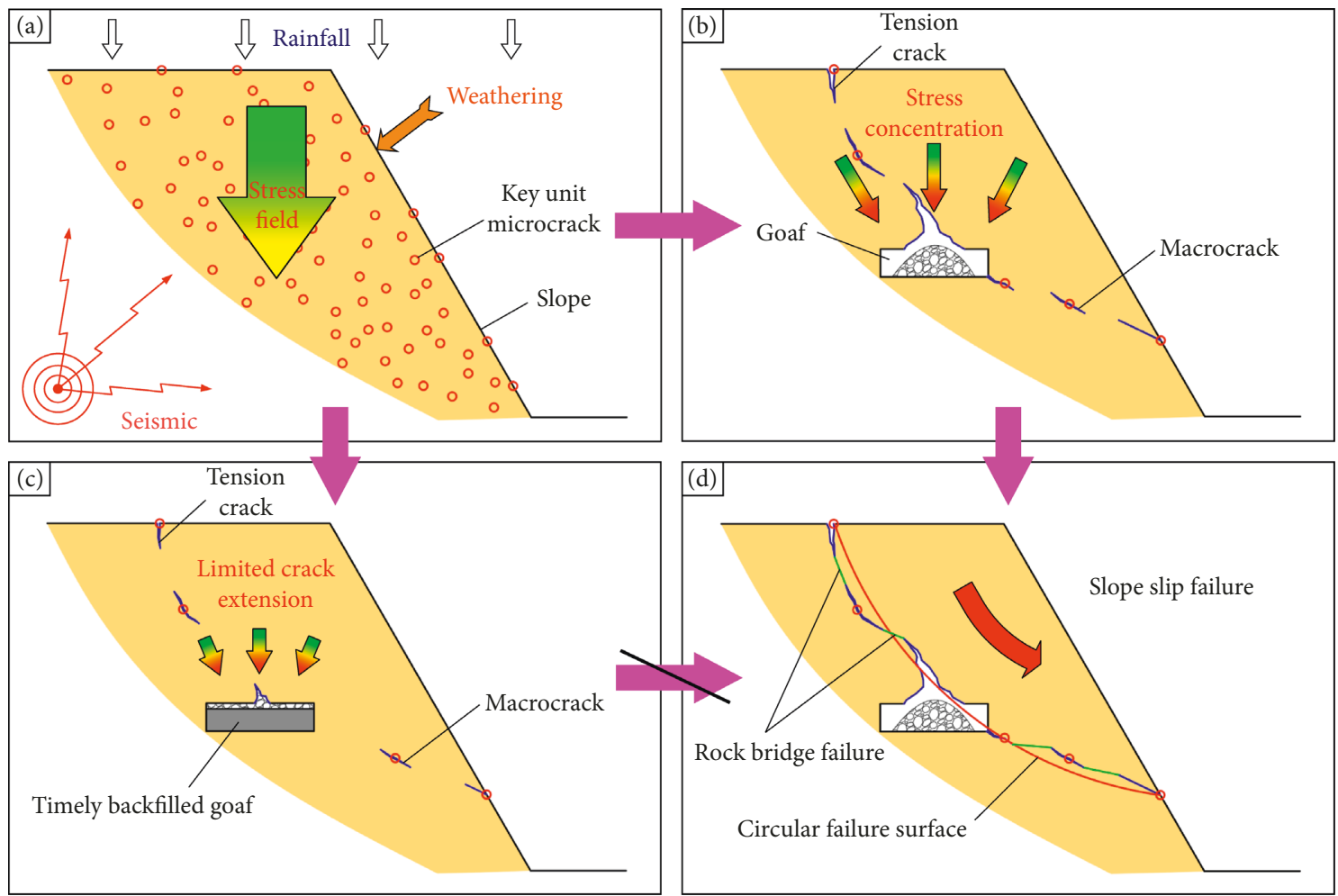

FIGURE 10: Failure mechanism of HSRS: (a) primary rock slope; (b) crack extension using open-stope mining method; (c) limited crack extension using backfill mining method; (d) circular failure surface.

point along the potential slip surface to the slope boundary, and eventually creates a circular failure surface. When goafs are backfilled promptly, the stress concentration decreases, and the crack extension process is slowed down (Figure 10(c)). Once the crack extension reaches a certain level, the limited roof-contacted space caused by the backfill mining 
method is filled by broken rocks and crack extension stops, and the evolution of circular failure surface is halted (Figure 10(d)).

\section{Conclusions}

(1) According to a geotechnical investigation and a series of laboratory tests, the geological model of HSRS in Zhangcunping Town was constructed based on the engineering parameters of the rock mass.

(2) In stability analysis, the average safety factors of HSRS for normal operation are 1.575 (backfill method) and 1.509 (open-stope method), and for seismic conditions, they are 1.470 (backfill method) and 1.380 (open-stope method). Compared with the biggest Chinese standard values, using the backfill mining method for HSRS shows substantially better seismic stability and lower potential destruction.

(3) It is found from the confidence level evaluation that the HSRS has a low failure probability and high reliability index based on the backfill mining method in normal operation.

(4) Because goafs are backfilled promptly, the limited roof-contacted space will be filled by broken rocks and, with a decrease in stress concentration, the crack extension process is stopped, and the evolution of the circular failure surface is halted. Therefore, the backfill mining method can reduce the destructive effect of mining to a minimum and ensure the stability of HSRS. Thus, the 6.3 million tons of highquality phosphate resources located in the banned area can be utilized safely using the backfill mining method.

\section{Data Availability}

The data used to support the findings of this study are available from the corresponding author upon request.

\section{Conflicts of Interest}

The authors declare that they have no conflicts of interest.

\section{Acknowledgments}

The authors thank the financial supports from the National Key R\&D Program of China (2017YFC0804605) and the National Natural Science Foundation of China (51804337).

\section{References}

[1] J. W. Zhao, X. M. Wang, K. Peng, and S. Li, "Utilization of foaming technology in cemented paste backfill of high-mud superfine unclassified tailings," Advances in Materials Science and Engineering, vol. 2017, Article ID 6157869, 7 pages, 2017.

[2] S. Li, Q. Chen, and X. Wang, "Superiority of filtered tailings storage facility to conventional tailings impoundment in southern rainy regions of china," Sustainability, vol. 8, no. 11, p. 1130, 2016.
[3] Q. Chen, Q. Zhang, A. Fourie, and C. Xin, "Utilization of phosphogypsum and phosphate tailings for cemented paste backfill," Journal of Environmental Management, vol. 201, pp. 19-27, 2017.

[4] J. Deng and L. Bian, "Investigation and characterization of mining subsidence in Kaiyang phosphorus mine," Journal of Central South University of Technology, vol. 14, no. 3, pp. 413-417, 2007.

[5] L. Jiang, L. Hu, and X. Lai, "Investigation on the threshold control of safety blasting vibration velocity for the extraction of complicated orebody under railway," Mining Science and Technology (China), vol. 21, no. 2, pp. 169-174, 2011.

[6] D. Mendjel and S. Messast, "Development of limit equilibrium method as optimization in slope stability analysis," Structural Engineering and Mechanics, vol. 41, no. 3, pp. 339-348, 2012.

[7] Y. H. Wang, S. R. Ge, and G. L. Guo, Probabilistic Methods on Slope Stability Analysis at Gol-E-Gohar Iron Mine, Mining Science and Technology, Xuzhou, China, 2004.

[8] R. C. Tiwari, N. P. Bhandary, and R. Yatabe, "Spectral element analysis to evaluate the stability of long and steep slopes," Acta Geotechnica, vol. 9, no. 5, pp. 753-770, 2014.

[9] H. N. Gharti, D. Komatitsch, V. Oye, R. Martin, and J. Tromp, "Application of an elastoplastic spectral-element method to 3D slope stability analysis," International Journal for $\mathrm{Nu}$ merical Methods in Engineering, vol. 91, no. 1, pp. 1-26, 2012.

[10] L. W. Abramson, T. S. Lee, S. Sharma, and G. M. Boyce, Slope Stability and Stabilization Methods, John Wiley \& Sons, Hoboken, NJ, USA, 2002.

[11] N. Dadashzadeh, H. S. B. Duzgun, and N. Yesiloglu-Gultekin, "Reliability-based stability analysis of rock slopes using numerical analysis and response surface method," Rock Mechanics and Rock Engineering, vol. 50, no. 8, pp. 2119-2133, 2017.

[12] H. Hamedifar, R. G. Bea, J. M. Pestanana-scimento, and E. M. Roe, "Role of probabilistic methods in sustainable geotechnical slope stability analysis," Procedia Earth and Planetary Science, vol. 9, pp. 132-142, 2014.

[13] J. a. L. Macneil and R. G. Dimitrakopoulos, "A stochastic optimization formulation for the transition from open pit to underground mining," Optimization and Engineering, vol. 18, no. 3, pp. 793-813, 2017.

[14] H. Jang, E. Topal, and Y. Kawamura, "Decision support system of unplanned dilution and ore-loss in underground stoping operations using a neuro-fuzzy system," Applied Soft Computing, vol. 32, pp. 1-12, 2015.

[15] J. Deng, Z. Q. Yue, L. G. Tham, and H. H. Zhu, "Pillar design by combining finite element methods, neural networks and reliability: a case study of the Feng Huangshan copper mine, China," International Journal of Rock Mechanics and Mining Sciences, vol. 40, no. 4, pp. 585-599, 2003.

[16] Chinese National Standard, Technical Code for Building Slope Engineering, Chinese National Standard, Beijing, China, 2013, in Chinese.

[17] L. He, X. M. An, G. W. Ma, and Z. Y. Zhao, "Development of three-dimensional numerical manifold method for jointed rock slope stability analysis," International Journal of Rock Mechanics and Mining Sciences, vol. 64, pp. 22-35, 2013.

[18] G. J. Wang, L. W. Yuan, X. Y. Kong, and L. M. Yin, Application of Slide for Stability and Uncertainty Analysis of Slope Engineering, Metallurgical Industry Press, Beijing, China, 2015, in Chinese.

[19] D. M. Zhang, S. Li, X. M. Wang, and Y. He, "Super large-scale filtered tailing disposal on coal-mining subsidence land," 
Polish Journal of Environmental Studies, vol. 26, no. 4, pp. 1855-1863, 2017.

[20] S. Y. Liu, L. T. Shao, and H. J. Li, "Slope stability analysis using the limit equilibrium method and two finite element methods," Computers and Geotechnics, vol. 63, pp. 291-298, 2015.

[21] Q. Liu, S. Li, X. Wang, and Y. He, "Feasibility and stability analysis of coal-gangue-based tailings dam on subsidence land," Fresenius Environmental Bulletin, vol. 27, no. 1, pp. 35-47, 2018.

[22] Chinese National Standard, Code for Investigation of Geotechnical Engineering, Chinese National Standard, Beijing, China, 2009, in Chinese.

[23] Chinese National Standard, Technical Code for Non-Coal Open-Pit Mine Slope Engineering, Chinese National Standard, Beijing, China, 2014, in Chinese.

[24] Chinese National Standard, Seismic Ground Motion Parameters Zonation Map of China, Chinese National Standard, Beijing, China, 2015, in Chinese.

[25] Chinese National Standard, Code for Seismic Design of Buildings, Chinese National Standard, Beijing, China, 2010, in Chinese.

[26] D. Stead and A. Wolter, "A critical review of rock slope failure mechanisms: the importance of structural geology," Journal of Structural Geology, vol. 74, pp. 1-23, 2015.

[27] S. H. Jiang, D. Q. Li, Z. J. Cao, C. B. Zhou, and K. K. Phoon, "Efficient system reliability analysis of slope stability in spatially variable soils using monte carlo simulation," Journal of Geotechnical and Geoenvironmental Engineering, vol. 141, no. 2, article 04014096, 2015.

[28] Y. Wang, Z. Cao, and S. K. Au, "Efficient monte carlo simulation of parameter sensitivity in probabilistic slope stability analysis," Computers and Geotechnics, vol. 37, no. 7-8, pp. 1015-1022, 2010.

[29] Z. X. Xu and X. P. Zhou, "Three-dimensional reliability analysis of seismic slopes using the copula-based sampling method," Engineering Geology, vol. 242, pp. 81-91, 2018.

[30] U. M. K. Eidsvig, A. Mclean, B. V. Vangelsten et al., "Assessment of socioeconomic vulnerability to landslides using an indicator-based approach: methodology and case studies," Bulletin of Engineering Geology and the Environment, vol. 73, no. 2, pp. 307-324, 2014.

[31] M. A. Brideau, M. Yan, and D. Stead, "The role of tectonic damage and brittle rock fracture in the development of large rock slope failures," Geomorphology, vol. 103, no. 1, pp. 30-49, 2009.

[32] J. Wang, L. Yao, and A. Hussain, "Analysis of earthquaketriggered failure mechanisms of slopes and sliding surfaces," Journal of Mountain Science, vol. 7, no. 3, pp. 282-290, 2010.

[33] L. A. M. Camones, E. D. A. J. Vargas, R. P. De Figueiredo, and R. Q. Velloso, "Application of the discrete element method for modeling of rock crack propagation and coalescence in the step-path failure mechanism," Engineering Geology, vol. 153, pp. 80-94, 2013. 


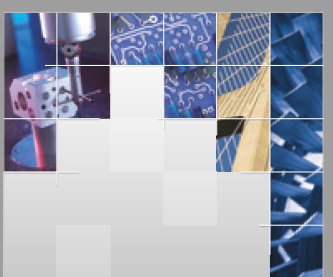

\section{Enfincering}
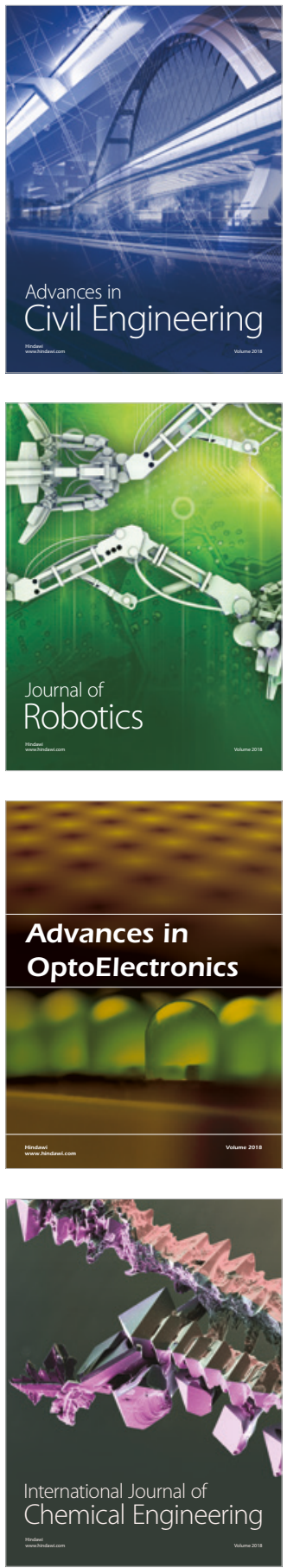

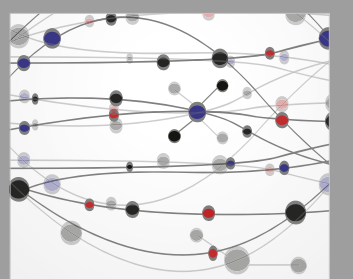

\section{Rotating \\ Machinery}

The Scientific World Journal

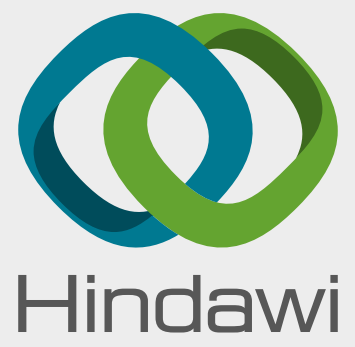

Submit your manuscripts at

www.hindawi.com
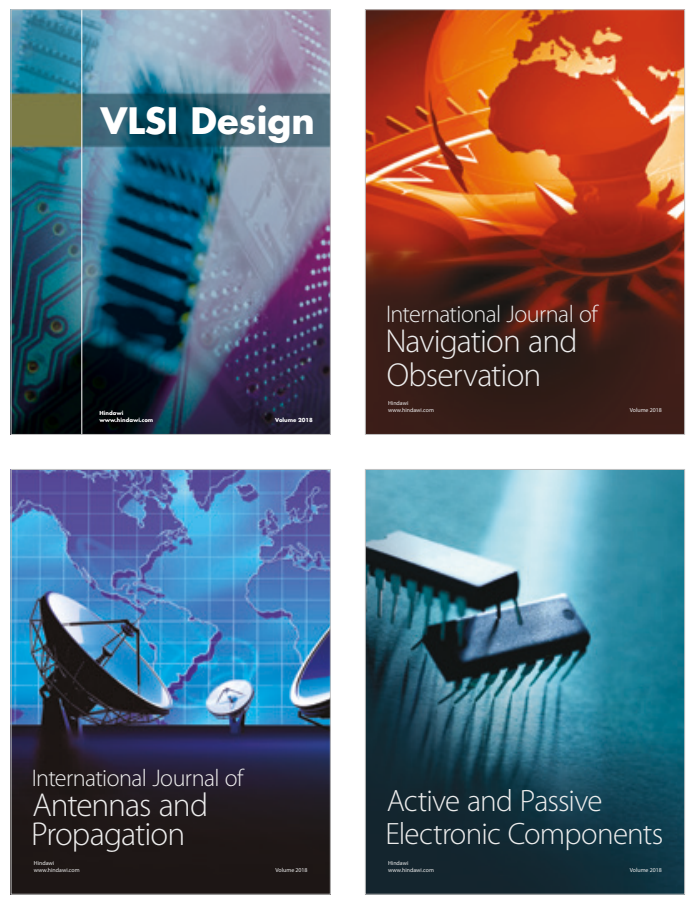
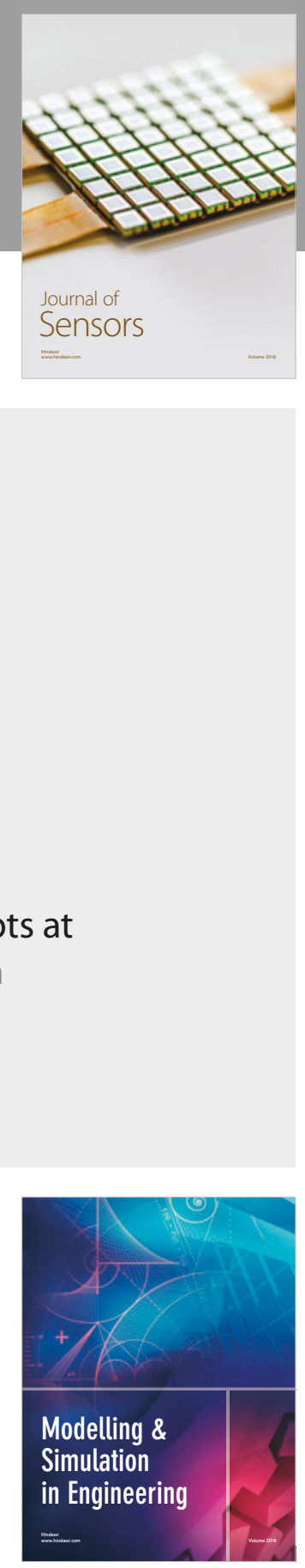

\section{Advances \\ Multimedia}
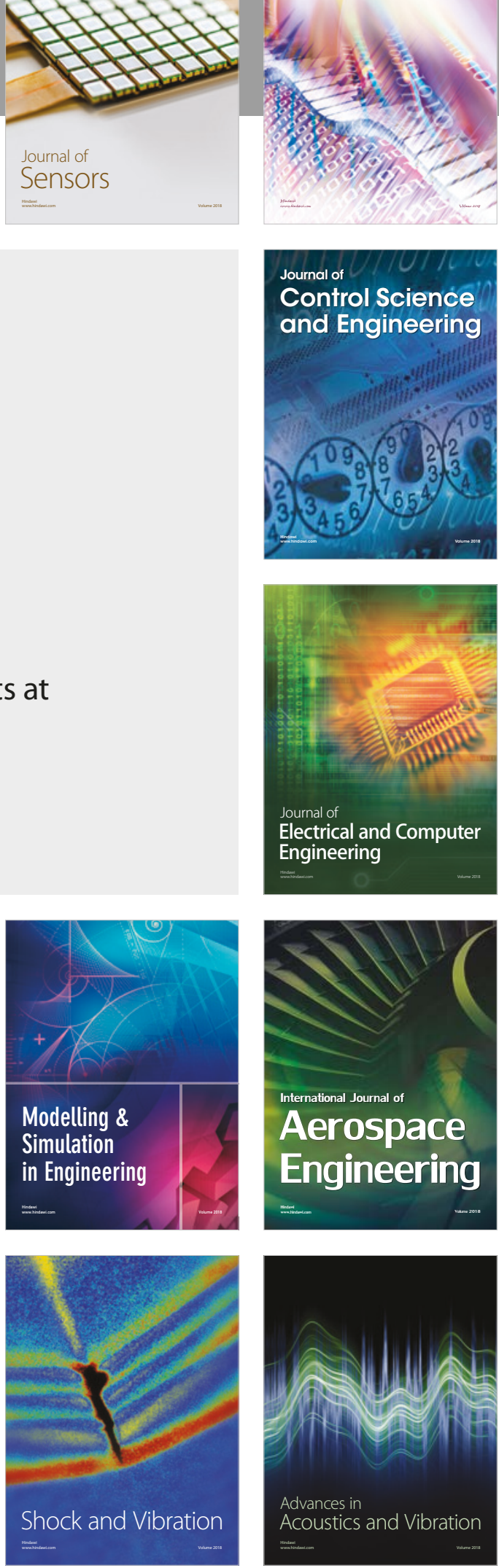